sistään ja tuntemuksistaan, kommentoi ja tekee päätelmiä. Parasta kaikessa on kuitenkin Kotilaisen vilpitön kiinnostus ja intomielinen asenne, jolla hän kertoo suomen kielen menestystarinaa. Se on aivan muuta kuin se kyyninen vähättely, jota fennisti on joutunut turhan usein kuulemaan jopa omiensa joukossa. Suomen kieli on hieno kieli! Toivottavasti sen ystävien joukko kasvaa entisestään Lari Kotilaisen teoksen myötä.

\section{KAISA HÄKKINEN etunimi.sukunimi@utu.fi}

\section{Lähteet}

Codices Fennici. Suomen keskiajan ja 150o-luvun käsikirjoitukset. www.codicesfennici. fi (11.7.2017).

Hakulinen, Auli - Kalliokoski, Jyrki

- KankaAnpä̈̈, Salli - Kanner, Antti - Koskenniemi, Kimmo -

Laitinen, Lea - MaAmies, Sari

- Nuolijärvi, Pirkko 2009: Suomen kielen tulevaisuus. Kielipoliittinen toimintaohjelma. Helsinki: Kotimaisten kielten tutkimuskeskus.
HitdenmaA, Pirjo 2003: Suomen kieli who cares? Helsinki: Otava.

Kotilainen, Lari 2009: Suomensuojelija. Ohjekirja kielen pelastamiseen. Helsinki: WSOY.

Lehtinen, TAPANi 2007: Kielen vuosituhannet. Suomen kielen kehitys kantauralista varhaissuomeen. Tietolipas 215. Helsinki: Suomalaisen Kirjallisuuden Seura.

Sulkunen, Irma 2004: Suomalaisen Kirjallisuuden Seura 1831-1892. Suomalaisen Kirjallisuuden Seuran toimituksia 952. Helsinki: Suomalaisen Kirjallisuuden Seura.

Suomen kieli. Opiskelijan tietokirja 1-3. Turun yliopiston suomen ja sen sukukielten oppiaineen julkaisuja 1. Turun yliopiston suomen kielen ja suomalais-ugrilaisen kielentutkimuksen julkaisuja 1, 5 . Päätoimittaja Kaisa Häkkinen. Turku 2011-2014.

YLIKOSKI, Jussi 2016: The origins of the western Uralic s-cases revisited. Historiographical, funtional-typological and Samoyedic perspectives. - FinnischUgrische Forschungen 63 s. 6-73.

\title{
Politiikan kielen analyysia yleistajuisesti
}

\section{Vesa Heikkinen \& Tapio Pajunen: Kansalaistaito. Miten politiikkaa voi ymmärtää, jos sitä voi ymmärtää? Helsin- ki: Teos 2016. 352 s. ISBN 978-951-851-700-2.}

Kieli on vallan väline, ja politiikka on kielen käyttöä. Siten politiikan ja kielen suhteen ymmärtämistä ja taitoa eritellä poliittista kieltä voidaan pitää kansalaistaitona, johon on perinteisesti luettu yhteiskunnallisia toimintavalmiuksia ja taitoa ajatella kriittisesti (ks. esim. Belt \& Tuusvuori 2017). Vesa Heikkisen ja Tapio Pa- jusen teos Kansalaistaito pureutuu politiikan kieleen ja teksteihin. Tekijät ovat paitsi alan asiantuntijoita myös kokeneita toimittajia. Heikkinen on tutkinut pitkään kielen ja vallankäytön suhdetta, ja Pajunen on politiikan toimittaja. Yhdessä he ovat tehneet Yleisradiossa ohjelmia kielestä ja politiikasta.

Kansalaistaito pyrkii tarjoamaan työkaluja politiikan tekstien tulkitsemiseen sekä tekemään kielen ja politiikan suhdetta ymmärrettäväksi ja näin kehittämään politiikan "sisälukutaitoa". Teos 
opastaa "tee se itse" -kielitieteeseen: tekijöiden mukaan kaikki voivat olla kielitieteilijöitä, kun oppii "erittelemään tekstejä ja antamaan niiden eri ilmiöille nimiä" (s. 323). Teos pohjautuu vankasti kielen- ja tekstintutkimukseen, johon yhdistyy politiikantutkimuksen asiantuntemus. Kirjoittajat määrittelevät teoksensa yleistajuiseksi tietokirjaksi, joka sopii äänestäjän oppaaksi mutta myös poliitikkojen kieli- ja tekstioppaaksi. Teosta voi siten arvioida monesta näkökulmasta. Tässä arviossa painottuu kielentutkijan näkökulma. Poliittisen retoriikan näkökulmasta teosta on laajasti käsitellyt Tilli (2017).

\section{Sanaluokat "tee se itse" -kielitieteen perustyökaluna}

Teos rakentuu viidestä numeroidusta pääluvusta sekä esipuheesta ("Kansalaiselle"), johdannosta ("Aivan aluksi") ja loppuluvusta ("Loppupeleissä"). Ensimmäinen luku ("Kielen politiikka") keskittyy sanoihin ja käsittelee niiden käyttöä sanaluokittain, kun taas muissa luvuissa tarkastellaan ilmiöitä laajemmin. Alussa tarjotaan siis yksittäisiä työkaluja kielen analysointiin, mikä on ymmärrettävä lähtökohta, onhan politiikan kielessä olennaista se, millaista sanastoa käytetään: sanavalinnoilla voidaan leimata, hämärtää asioita ja synnyttää päämäärän mukaan erilaisia merkityksiä. Alaluvuissa käsitellään politiikan substantiiveja, verbejä, adjektiiveja, numeraaleja ja lopuksi politiikan pikkusanoja. Kunkin alaluvun alussa on tietolaatikko, jossa esitellään kyseinen sanaluokka ja kerrotaan sen yleisyydestä. Sanaluokat tarjoavat selkeän lähtökohdan politiikan kielen tarkastelulle. Toisaalta ne tekevät tekstin rakenteesta hieman raskaan, vaikka sitä onkin kevennetty huumorilla ja letkeällä kielellä. Sanaluokissa on paikoin myös vaikea pysytellä, kun ilmiöt johdattavat tarkastelemaan asioita yksittäisiä sanoja laajemmin.

Sanaluokista suurimman huomion saavat substantiivit, mikä osoittaa niiden keskeisyyttä: "[i]lman substantiiveja, nimisanoja, ei ole taloutta, ei politiikkaa", kirjoittajat korostavat (s. 31). Substantiivien alla on ollut myös mahdollista käsitellä monenlaisia poliittisen kielenkäytön ilmiöitä, kuten kansa-sanan käyttöä, maahanmuuttajien nimeämistä, kielellistä abstraktiutta ja metaforisuutta.

Verbejä koskevassa luvussa huomion kohteena ovat muun muassa eri poliitikkojen käyttämät tai heihin liitetyt verbit (esim. Mauno Koiviston fundeerata, Juha Sipilän vatuloida ja Timo Soiniin yhdistetty jytkyttää). Verbien käyttöä tarkastellaan muun muassa modaalisuuden ja modusten sekä merkityskategorioiden kautta. Lukijalle esitellään myös systeemis-funktionaalisen kieliopin käsitteet suhdelause, materiaalinen lause ja mentaalinen lause, joiden avulla voidaan luonnehtia presidenttien uudenvuodenpuheille ominaista retoriikkaa (ks. Halliday 1994).

Adjektiiveille omistetussa luvussa lähdetään liikkeelle jakamalla adjektiivit absoluuttisiin, suhteellisiin ja arvottaviin. Tarkastelu kiinnittyy vertailumuotojen käyttöön sekä informaatiorakenteen kannalta siihen, kuinka tuttuna tai yleisesti hyväksyttynä adjektiivilla ilmaistu ominaisuus esitetään. Yksittäisistä adjektiiveista huomio kohdistetaan muun muassa sanojen hyvä ja oikea ja niiden vastakohtien käyttöön ja yleisyyteen. Tarkastelun kohteena ovat myös sellaiset ilmaukset kuin On hyvä, että lakivaliokunta on ollut tosissaan, joita tekijät arvostelevat siitä, että niissä mielipidettä ei ole kielellisin keinoin merkitty mielipiteeksi, vaan puhuja esittää sen totuuden kaavussa. "Jos edustajat haluaisivat kertoa asioiden todellisen laidan, he käyttäisivät sanoja mielestäni tai meidän mielestämme tai vaikkapa kokoomuksen mielestä" (s. 62-63). Mutta jos edustaja arvottaa asian käyttämällä laatua ilmaisevaa adjektiivia, kyllähän hän ilmaisee mielipiteensä. Toinen asia on, että sivulauseessa oleva asia pre- 
supponoidaan totuutena. Presuppositioita tekijät eivät kuitenkaan käsittele.

Adjektiivi-luvussa tarkastellaan myös sitä, miten vähävaraisiin viitataan ja käytetäänkö substantiivia vai adjektiivia. Köyhyyspuheen analyysi sisältää kiinnostavia havaintoja, kuten jo otsikko "Köyhä, vähävarainen vai peräti heikompi aines?" osoittaa. Samalla alaluku on esimerkki siitä, miten moniaalle lyhyessä tekstissä haarotaan: verrataan substantiivien ja adjektiivien käyttöä, käsitellään köyhä-sanan synonyymejä ja analysoidaan köyhyyskeskustelua.

Numeroilla voidaan tehdä monenlaisia asioita, kuten tekijät osoittavat numeraaleja käsittelevässä luvussa. Niillä myös "hämätään ja hölynpölytetään, valehdellaankin" (s. 84). Maahanmuutosta käytävä keskustelu on havainnollinen esimerkki siitä, miten määrällistäminen ("eli maailma numeroina") etäännyttää asioiden tarkastelun ihmisistä, joita numerot kuvaavat.

Politiikan pikkusanoihin kirjoittajat sisällyttävät pronominit ja partikkelit (adverbit, adpositiot, konjunktiot ja interjektiot). Pronomineja käsitellään eniten, tosin useissa esimerkeissä ei esiinny pronomineja lainkaan vaan persoonamuoto ilmenee vain verbin taivutuksesta. Siten väite siitä, että me olisi yleisin pronomini presidenttien puheissa, jää mietityttämään. Tässä olisi ollut parempi puhua väljemmin viittausmuodoista (kuten alaluvussa "Minä, kaikkivaltias" tehdäänkin). Vaikkei ratkaisu olisi ollut teoksen rakenteen kannalta ihanteellinen, se olisi antanut mahdollisuuden tarkastella myös esimerkiksi passiivin käyttöä. Muiden "pikkusanojen" tarkastelu jää luvussa vähäiseksi, joskin jo esimerkiksi puhe "vihjailuadverbeista" (esim. SMP taktikoi taas budjetilla) viittaa partikkelien merkitykseen poliittisessa kielenkäytössä.

\section{Tekstien analyysia}

Toisessa pääluvussa ("Pelin henki") tarkastelu laajenee kielellisistä yksityiskoh- dista genreihin eli tekstilajeihin. Lukuun johdatellaan politiikan peli -metaforan avulla: politiikan kielipelejä pelataan genrejen säännöillä tai niitä rikkoen. Ennen varsinaisia alalukuja on tietolaatikko siitä, mitä genrellä eli tekstilajilla tarkoitetaan. Sen selityksessä tekijät lähtevät tekstin käsitteestä ja määrittelevät tekstilajin lyhyesti siten, että se viittaa tekstien samankaltaisuuksiin. Luku sisältää kiinnostavia esimerkkejä eri tekstilajeista, niiden vakiintumisesta ja genresääntöjen rikkomisesta. Luvussa myös verrataan eri poliitikkojen puhetyylejä ja eri aikoina pidettyjä puheita. Tekstilajien moninaisuutta käsitellään uudenvuodenpuheista eduskuntapuheisiin ja valtiopäiväasiakirjoista tviitteihin.

Kirjan esimerkit kattavat pitkän ajanjakson: osa on hyvin ajankohtaisia, ja jotkut nousevat uudelleen ajankohtaisiksi, kuten alaluvun "Ohjelmien ketju eli kuinka Nuivan tekstiä päätyi hallitusohjelmaan" esimerkki tekstien siirtymisestä toisiin teksteihin. Tekijät osoittavat yksityiskohtaisesti, miten perussuomalaiset ovat saaneet hallitusohjelmaan konkreettisia toimenpide-ehdotuksiaan. Kesäkuussa 2017 pidetyn perussuomalaisten puoluekokouksen ja sitä seuranneiden tapahtumien valossa esimerkki antaa tapahtumille taustaa, joka osaltaan voi vahvistaa käsitystä politiikasta teatterina.

Kolmannessa pääluvussa ("Yhteiskunta, sovun sija") tarkastellaan yhteiskuntasopimusta ja sopimusyhteiskuntaa. Luku on eheä narratiivinen kokonaisuus, "yhteiskuntasopimustarina", jossa piirretään laaja historiallinen kaari painopisteen ollessa Juha Sipilän ajamassa kilpailukykysopimuksessa.

Neljännessä pääluvussa ("Totuuden valheet") kohteena on politiikan suhde totuuteen. Aihe on hyvin ajankohtainen: marraskuussa 2016 Oxfordin sanakirjojen toimitus valitsi vuoden sanaksi ilmauksen post-truth eli 'totuudenjälkeinen', joka viittaa siihen, että tunteet ja henkilökoh- 
taiset uskomukset vaikuttavat politiikan teossa yleisen mielipiteen muokkaamiseen faktoja enemmän (Oxford Dictionaries 2016). Käsite ei ole vielä ehtinyt Heikkisen ja Pajusen teokseen, vaikka ajatus siitä on mukana, kun he toteavat, että "valehtelu ja hölynpöly ovat kaikesta päätellen normaalistuneet" ja että "erilaiset rajat hämärtyvät, myös faktan ja fiktion rajat" (s. 256-257). Kiinnostava kysymys on, miten totuus tai sen puuttuminen olisi tunnistettavissa kielenkäytöstä. Luvun toinen puoli käsittelee luottamusta ja lupauksia, joissa käsittelyn pohjaksi löytyvätkin totuutta helpommin kielelliset ilmaukset. Mielenkiintoinen havainto on luvun lopussa esitetty anteeksipyyntöpuheen yleistyminen. Yksi esimerkki on pääministeri Aleksanteri Stubbin lausahdus Sori siitä, jolla hän pyysi anteeksi hallintarekisterihankkeen yhteydessä esittämäänsä väärää prosenttilukua. Kun hanke ensin lopullisesti haudattiin, mutta vietiin myöhemmin kuitenkin läpi, tarjoaisi siitä käyty keskustelu jatkotutkimukselle kiinnostavaa aineistoa.

Viidennessä luvussa ("Persoona pelissä") keskiössä on poliitikon persoona ja erityisesti Jyrki Katainen ja hänen kielenkäyttönsä, kuten hehkutuspuhe ja sille leimallinen adjektiivi fantastinen. Kiinnostavaa on pohdinta, miten aikaisemmasta perinteestä poikkeava tyyli on mahdollista, sekä erilaisten puhetyylien vertailu ja niiden asettaminen ajalliseen kontekstiin.

\section{Poleemisesti ja letkeästi}

Teos sisältää runsaasti havainnollisia ja herkullisia esimerkkejä. Analyyseista erityisen antoisia ovat yksityiskohtia laajemmat tapaukset, joissa tarkastellaan esimerkiksi sitä, miten tekstit vaikuttavat toisiinsa tai miten jokin asia käsitteellistetään ja ilmaistaan eri aikoina ja poliittisessa kontekstissa eri tavoin. Loppuluvussa tekijät toteavat, että he ovat poli- tiikan olemusta etsiessään välillä "poikenneet sivupoluillekin" (s. 322). Kieltämättä tällainen vaikutelma toisinaan syntyy; teos vakuuttaa runsaalla esimerkkiaineistollaan, joka ehkä osaltaan on johdattanut noille sivupoluille.

Paikoin olisin kaivannut väitteille enemmän perusteluja. Esimerkiksi väite "Persoonapronominien minä, sinä, hän, me, te ja he arvellaan olevan itsestään selviä tai tylsiä tai valjuja jopa merkityksettömiä” (s. 8) herättää kysymyksen, kuka näin on arvellut, missä yhteydessä ja miksi. Toinen esimerkki on väite "Martti Ahtisaaren ja Tarja Halosen puheita leimaa päälausevoittoisuus ja tietynlainen liioiteltukin yksinkertaisuus", jonka todisteeksi on poimittu yksi virke molemmilta (s. 116-117). Kielentutkimuksen näkökulmasta yksi virke tekstimassasta ei vielä kuitenkaan riitä kuvaamaan tutkittuja aineistoja.

Teoksen tyyli on poleeminen. Teksti herättää paikoin myös vastaväitteitä. Voi esimerkiksi kysyä, mistä näkökulmasta "kikkailu on kekseliästä, jotenkin hyvä ja kannatettava asia" (s. 35), jos puhutaan verokikkailusta. Yleistykset ja kärjistykset herättävät huomiota, mutta vaarana on, että ne vievät pohjaa pois asialliselta argumentaatiolta. Tässä pari esimerkkiä kärjistyksistä: "Ilman nimenantamista ja -käyttämistä ei ole vuorovaikutusta eikä valtaa" (s. 31) ja "Substantiivien suosiminen voi olla perusteltua siitä syystä, että asia halutaan tietoisesti etäännyttää kansalaisista" (s. 65).

Poleemisuutta korostavat otsikot, kuten "Numerolla päähän ja pulinat pois!" ja "Metaforien tulva yli totuuden". Esimerkkiotsikot ohjailevat voimakkaasti tulkintaa siitä, mitä kyseisillä ilmauksilla tehdään. Huutomerkkiä on käytetty myös muualla tekstissä melko runsaasti ohjailemaan lukijan huomiota: "Lainlaatijat eli kansanedustajat puuttuvat usein lainvalmistelun heikkouksiin, liialliseen oikeudellistumiseen ja lakikielen vaikeaselkoitusuuteen. Erikoista!" (S. 147.) Vastaavasti lukijaa he- 
rätellään myös kysymyslausein ("Tippuiko kansa kärryiltä?" s. 30) tai pelkin väitelausein ("Aikamoinen soppa." s. 157).

Letkeä kieli on osa teoksen huumoria. Tämä näkyy paitsi otsikoissa myös muualla tekstissä, esimerkiksi alaluku "Luottamus, tuo totuuden kyty" alkaa näin: "Totuuden veli on luottamus. No, serkku ainakin. Vai sittenkin vain kyty eli aviomiehen veli..." (S. 235.)

Teos on yleisilmeeltään helppolukuinen. Samalla kun toisaalta on pyritty yleistajuiseen tietoteokseen, tekijöiden asiantuntemus tulee monin tavoin esiin, esimerkiksi jo mainituin tietolaatikoin. Kielen- ja erityisesti systeemis-funktionaalisen tekstintutkimuksen käsitteitä on käytetty ja avattu ymmärrettävästi asiaa tuntemattomalle lukijalle (esim. kieliopillinen metafora, informaatiorakenne). Tieteellistä vakuuttavuutta lisäävät loppuviitteiksi sijoitetut lähteet, pitkä lähdeluettelo, jonka otsikkona on "Lähteet ja kirjallisuus" (olisiko pelkkä "Lähteet" riittänyt?), ja asia- ja henkilöhakemisto. Valitettavasti lähdeluettelon ja hakemiston luettavuutta heikentää erittäin pieni kirjasinkoko.

Kuvituksena toimivat päälukujen alussa olevien valokuvien lisäksi mustat ja harmaat puhekuplat, jotka sisältävät sitaatteja erilaisista puheista ja kirjoituksista. Sitaatit havainnollistavat hyvin tekstiä (tosin sitaatteja on yhtä lailla myös tekstin sisällä), mutta jälleen lukemista vaikeuttavat pieni kirjasinkoko ja toisaalta väri (mustalla pohjalla valkoinen teksti). Mustia puhekuplia on joillakin aukeamilla runsaasti; pitemmät harmaat kuplat taas voivat peittää puoli sivua, eikä pitkien sitaattien funktio aina aukene.

\section{Lopuksi}

Teos nostaa esiin kiinnostavia ilmiöitä ja saa pohtimaan politiikan kielenkäyttöä.
Se myös herättää kysymyksiä. Kirjan lukuisat esimerkit selittävät sitä, miksi suuri osa suomalaista kokee politiikan liian monimutkaiseksi ja vaikeasti ymmärrettäväksi (vrt. Borg, Kestilä-Kekkonen \& Westinen 2015: 57). Yksi esiin nousseita kysymyksiä on, mikä ero on selkeällä, yksinkertaisella kielellä ja populismilla, "joka perustuu tietynlaiseen selväkielisyyteen" (s. 246), ja miten laajoja konteksteja ja taustatietoja tarvitaan vastauksen antamiseen.

Heikkisen ja Pajusen teos sisältää painavaa asiaa ja saa toivottavasti kansalaiset kiinnittämään huomiota politiikan kieleen. On myös tärkeää, että politiikan kielen tutkijat kirjoittavat ymmärrettävästi ja laajaa yleisöä kiinnostavasti aiheesta. Kielentutkijalle teos tarjoaa monia herkullisia aiheita tarkemmin tutkittavaksi.

\section{LIISA TIITTULA etunimi.sukunimi@helsinki.fi}

\section{Lähteet}

Belt, JAAKKo - TuUsvuori, JARkKo S. 2017: Kansalaistaitojen käsitteestä. - Niin \& Näin 1/2017 s. 45-47.

Borg, SAMI - Kestil Ä-KeKKonen, Elina - Westinen, Jussi 2015: Demokratiaindikaattorit 2015. Helsinki: Oikeusministeriö.

Halliday, M. A. K. 1994: An introduction to functional grammar. Toinen, uudistettu laitos. London: Arnold.

Oxford Dictionaries. Word of the year 2016. https://en.oxforddictionaries.com/ word-of-the-year/word-of-the-year-2016 (22.6.2017).

Tilli, Jouni 2017: Ymmärrys hoi! Politiikka ja retoriikka kansalaistaitona. - Niin \& Näin 1/2017 s. 48-52. 